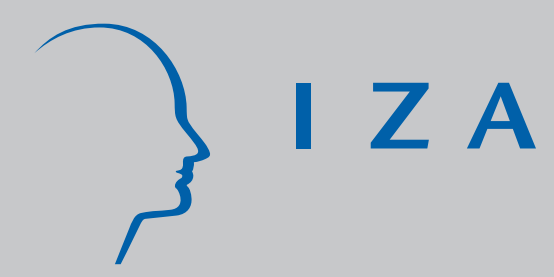

IZA DP No. 916

Why Some Firms Train Apprentices and Many Others Do Not

Stefan C. Wolter

Samuel Mühlemann

J ürg Schweri

October 2003 


\title{
Why Some Firms Train Apprentices and Many Others Do Not
}

\author{
Stefan C. Wolter \\ Swiss Coordination Centre for Research in Education, \\ University of Berne and IZA Bonn \\ Samuel Mühlemann \\ University of Berne \\ Jürg Schweri \\ University of Berne
}

Discussion Paper No. 916
October 2003

\author{
IZA \\ P.O. Box 7240 \\ D-53072 Bonn \\ Germany \\ Tel.: +49-228-3894-0 \\ Fax: +49-228-3894-210 \\ Email: iza@iza.org
}

This Discussion Paper is issued within the framework of IZA's research area The Future of Labor. Any opinions expressed here are those of the author(s) and not those of the institute. Research disseminated by IZA may include views on policy, but the institute itself takes no institutional policy positions.

The Institute for the Study of Labor (IZA) in Bonn is a local and virtual international research center and a place of communication between science, politics and business. IZA is an independent, nonprofit limited liability company (Gesellschaft mit beschränkter Haftung) supported by Deutsche Post World Net. The center is associated with the University of Bonn and offers a stimulating research environment through its research networks, research support, and visitors and doctoral programs. IZA engages in (i) original and internationally competitive research in all fields of labor economics, (ii) development of policy concepts, and (iii) dissemination of research results and concepts to the interested public. The current research program deals with (1) mobility and flexibility of labor, (2) internationalization of labor markets, (3) welfare state and labor market, (4) labor markets in transition countries, (5) the future of labor, (6) evaluation of labor market policies and projects and (7) general labor economics.

IZA Discussion Papers often represent preliminary work and are circulated to encourage discussion. Citation of such a paper should account for its provisional character. A revised version may be available on the IZA website (www.iza.org) or directly from the author. 
IZA Discussion Paper No. 916

October 2003

\section{ABSTRACT \\ Why Some Firms Train Apprentices and Many Others Do Not ${ }^{*}$}

The latest study investigating the cost-benefit ratio of apprenticeship training for Swiss companies has shown that most apprentices offset the cost of their training during their apprenticeship on the basis of the productive contribution of the work they perform. Given this outcome, it is worth investigating why so many firms choose not to train apprentices. Maximum likelihood selection models were used to estimate the net cost of training for firms without an apprenticeship programme. The models show, firstly, that non-training firms would incur significantly higher net cost during the apprenticeship period if they would switch to a training policy and secondly, that this less favourable cost-benefit ratio is determined less by cost than by absence of benefit. For the apprenticeship system as such the results indicate, that as long as training regulations and the market situation permit a cost effective training of apprentices, companies do not need specific labour market regulations or institutions to offer training posts. In this respect, the Swiss findings might be of interest for the on-going German discussion about the expected repercussions of a more general labour market deregulation on the apprenticeship training system.

JEL Classification: J24, J31, J44

Keywords: apprenticeship training, firm-sponsored training, cost-benefit analysis

Corresponding author:

Stefan C. Wolter

Swiss Coordination Centre for Research in Education

Entfelderstrasse 61

5000 Aarau

Switzerland

Email: stefanwolter@yahoo.de

\footnotetext{
* The study is based on two surveys financed by the Commission for Technology and Innovation (CTI credit 4289.1 BFS and 5630.1 BFS) with the help of the Swiss Federal Statistical Office and carried out in tandem with a similar survey in Germany conducted by the Federal Institute of Vocational Training (Bundesinstitut für Berufsbildung) in Bonn.
} 


\section{Introduction}

Considering the importance of vocational training for post-compulsory education and training (upper secondary level) in many countries, especially in Europe, there is a remarkable paucity of empirical studies investigating the economic determinants of this form of education. At the same time, the cyclical imbalance in apprenticeship supply and demand, and the structural decline in apprenticeships identified in some countries, make it now more important than ever to conduct an in-depth analysis of the reasons why some firms train apprentices while others do not. It is hoped that the studies on which this article is based will contribute to a better understanding of how the vocational training system works.

Studies investigating the factors determining a firm's willingness to train apprentices have always been based on the assumption that profit-maximising companies calculate the likely net cost of training an apprentice and, logically, offer an apprenticeship if the outcome is favourable and do not if the outcome is unfavourable. Past studies of this type lacked access to actual cost-benefit data on apprentice training. The only data on costs and benefits these studies were able to incorporate were certain macro- and mesodata, so-called stylised facts, about the costs (net costs at a later date) of apprenticeship training found in German, Austrian and Swiss studies. These analyses therefore in many cases did not constitute a sound basis for drawing conclusions as to the real factors motivating the companies concerned and determining their decisions.

The purpose of this paper is to present a closer investigation of companies' willingness to provide apprenticeships. A dataset will be used which has two significant benefits for a study with this kind of objective. For one, it is a large, up to date and representative dataset of training firms and provides precise details of the cost and benefit of the apprenticeship system. For another, the study includes a parallel analysis of non-training companies, allowing for the first time a systematic comparison in one dataset of training and non-training companies in terms of the cost-benefit ratio of training apprentices. 
The structure of the paper is as follows: The next section provides a brief description of the Swiss vocational training system, which is broadly similar to the German model but presents some particularities. The subsequent section describes the database for this study. The empirical part presents a cost-benefit analysis for firms that train apprentices and then uses selection models to investigate the likely cost-benefit ratios of non-training companies if they were to switch to a training policy. This investigation explores the net cost of training and involves a separate study of the costs and the benefit of implementing a training programme. The final section summarizes the results and comments on the implications of the results for the economy and for educational policy.

\section{Apprenticeship training in Switzerland - some stylised facts}

The apprenticeship system is the route chosen by most Swiss youngsters at upper secondary level. Around $60 \%$ of young people who complete their compulsory schooling choose to embark on what is called the dual education system, that is, a training programme combining vocational education at school with training in and work for a company. Almost half of the remaining $40 \%$ of young people who complete compulsory education go on to attend grammar school (Gymnasium) to prepare them for university and a more academic career. The remainder (just above $20 \%$ ) opt either for other entirely school-based forms of education or (less than $10 \%$ of a cohort of 16-year-olds) pursues no form of post-compulsory education, ranking Switzerland ahead of other OECD countries in terms of the percentage of the over-16 population attending school. Although employers' organisations often issue target salaries for apprentices, the apprentices salary is determined by the employing company and not regulated by law or on the base of multi-sectoral agreements ("Tarifvertrag") between trade union confederations and employers' confederations. Vocational training in a dual-education program usually lasts three to four years, and drop-out rates are fairly low, around 5\%. A few professions (mostly in the retail sector) still permit an apprenticeship period of just two years. Apprentices graduate with a diploma recognized throughout Switzerland attesting that the apprentice has a professional qualification. After, or during, an apprenticeship, a qualification called a "Berufsmatur" (professional 
baccalaureate) may be acquired which additionally entitles the apprentice to begin third-level studies at a university of applied science. The quality of the training provided in Switzerland, which combines school lessons (1-2 days a week) with on-the-job training in a firm under the supervision of certified staff, is recognized internationally as meeting top standards. ${ }^{2}$ International comparisons show that, in terms of scholastic and professional qualifications, Swiss apprentices are more than a match for their upper secondary level peers attending school full-time.

The employment period ends automatically on completion of training. Any extension of the employment period (making the apprentice a fully-fledged employee) must be negotiated in a separate contract. Switzerland differs in this respect from some other countries where apprentices are protected from dismissal for a period of time after completing their training. Mobility is fairly high among young people who complete their apprenticeship, with only $36 \%$ still working at their original training site one year on (see Schweri et al. 2003).

The quality of Swiss vocational training and (as the case may be) universities of applied science is evident from the fact that graduate apprentices usually have no problem finding a job (see, for instance, OECD 2000), and the associated returns on education are similar to those for young people attending school full-time (see Weber et al. 2001).

\section{Data}

The data used here is from two surveys conducted in Swiss firms in 2001 by the Centre for Research in Economics of Education at the University of Berne and the Swiss Federal Statistical Office (see Schweri et al. 2003 or Wolter and Schweri 2002). In the first survey, firms that trained apprentices in 2000 completed an extensive questionnaire investigating aspects related to the cost and benefit of training and eliciting information about the training site itself. Large sites with separate departments for dealing with staffing costs and training were given two copies of the questionnaire per site. The questionnaire was largely identical to one

\footnotetext{
${ }^{2}$ Few descriptions of the Swiss vocational education system exist in English. For example, the international review of the vocational education literature by Ryan (1998) does not mention Switzerland. For a qualitative comparison of Swiss vocational education versus the UK, see Bierhoff and Prais (1998).
} 
conducted in parallel for Germany by the Federal Institute of Vocational Education, Bonn (see Walden and Herget 2002 and Beicht and Walden 2002). The German survey in turn was an update based on improvement and adaptation of existing German studies (see von Bardeleben et al. 1995). The second survey was directed at firms that had not provided training in 2000. The questionnaire was identical to the one for firms providing training except that the questions relating directly to the cost and benefit of training did not apply.

The study differs from a prior Swiss study (see Hanhart and Schulz 1998) in four important respects. Firstly, the study is representative in terms of sampling and weighting. ${ }^{3}$ Secondly, both samples (training and non-training firms) represent enough respondents to allow analysis, even of subgroups, with sufficient statistical power. Thirdly, the study was occupation-specific. In other words, firms were asked about the specific occupations trained for and not about apprenticeship training in general. ${ }^{4}$ This proved to be a significant advantage, as the results show that the cost-benefit ratio of a training programme has more to do with the particular occupation than with the particular company or sector; hence, nonconsideration of occupation as a criterion is liable to skew the results and introduce bias. Finally, the study also factored in apprenticeship stage. One reason this is so significant is that small firms in particular do not always have young people at all stages of apprenticeship at a given time. A blanket survey for an entire apprenticeship period would hence have neglected fluctuations as regards stage (i.e. year) of apprenticeship. A survey centring on one particular apprenticeship stage (years) that happened to not be represented in the company at the time of questioning would have served to skew the results still further.

The dataset embraces 2,352 training firms and 2,230 non-training firms. 350 of the non-training firms that would not even in theory have been fit to provide

\footnotetext{
3 Sampling and computation of weightings for projections was done by the Swiss Federal Statistical Office (see Renfer 2002 and Potterat 2003). All estimations in this article are weighted by sampling weights accounting for the stratified sampling.

${ }^{4}$ For companies training apprentices in a number of occupations, a particular occupation was specified. These companies were allowed to reply in respect of several occupations, but were required to fill out separate questionnaires for this purpose. Some large companies did so. Nontraining firms said which occupation they would be most likely to provide training for if they were to start an apprenticeship programme. Non-training firms unable to specify a particular occupation were assigned to the "Other occupations" category.
} 
training due to organizational reasons ${ }^{5}$ were excluded from the sample. This loss of data was unavoidable due to the lack of any pool of company statistics on apprenticeship that might have been used for direct sampling. The actual sample was therefore taken from a pool of 40,000 firms from a prior screening procedure in which the firms were required to describe themselves as training or nontraining. ${ }^{6}$ For the calculations, all non-private firms were excluded as they do not maximise profits as assumed in our model. The actually used sample is therefore composed of 3,632 firms.

Table 1: Percentage of training and non-training firms used in the sample, by firm $\operatorname{size}^{7}$

\begin{tabular}{lccccc}
\hline \hline & \multicolumn{5}{c}{ Employees } \\
& $1-9$ & $10-49$ & $50-99$ & $100+$ & Total \\
\hline Non-training firms & $76.18 \%$ & $59.56 \%$ & $42.43 \%$ & $33.05 \%$ & $70.86 \%$ \\
Training firms & $23.82 \%$ & $40.44 \%$ & $57.57 \%$ & $66.95 \%$ & $29.14 \%$ \\
\hline \hline
\end{tabular}

\section{Empirical cost-benefit model}

Our examination of the costs and benefits that arise in relation to apprenticeship training focuses, in a first step, on the actual period of apprenticeship. The cost $(C)$ of an apprentice $(i)$ at a training site $(j)$ and in apprenticeship year $(t)$ are composed primarily of the apprentice's wage $\left(w^{a}\right)$, the trainers' wages $\left(w^{b}\right)$ times training time $\left(d^{0}\right)$, and the material and infrastructure expenses $(X)$ involved in providing the training. The number of apprenticeship years is $n$.

$$
C_{i j}^{a}=\sum_{t=1}^{n}\left(w_{i j t}^{a}+d_{i j t}^{0} \times w_{i j t}^{b}+X_{i j t}\right)
$$

The cost model shows that the dual educational system does not simply involve the apprentice working part of the week and attending school the rest of the time, but that part of the training takes place at the worksite. This is not the same as

${ }^{5}$ For example, a geographical outpost of a company with no decision-making autonomy and unequipped to provide training on grounds of size.

${ }^{6}$ Sample descriptives are in the appendix of this paper.

7 The values recorded in table 1 do not include non-training firms that would not even in theory have been fit to provide training, as explained in the text. 
ordinary on-the-job training because it normally takes place under the guidance of master journey-workers or other trainers who are specially trained to perform this task. It goes without saying that this form of training involves additional costs.

The benefit $\left(B^{a}\right)$ derived by the training site from apprenticeship training during the apprenticeship period results from the productive work performed by the apprentice when she or he is not being trained. This time is broken down into time for production activities that would otherwise be performed by unskilled workers $\left(d^{I}\right)$ and skilled workers $\left(d^{I I}\right)$. While we can assume in the first case that the apprentice's performance will have the same value as that of an unskilled worker, for the second case we asked what the productivity of the apprentice's performance would be compared to that of a fully trained skilled worker $(\gamma)$. Type I work was multiplied by the wages paid to an unskilled worker $\left(w^{u}\right)$, while for type II we took the wages paid to a skilled worker in the relevant occupation $\left(w^{s}\right)$.

$$
B_{i j}^{a}=\sum_{t=1}^{n}\left(d_{i j t}^{I} \times w_{j}^{u}+d_{i j t}^{I I} \times w_{j}^{s} \times \gamma_{i j t}\right)
$$

The net cost of apprenticeship training $(N C)$ was calculated by simply netting the cost (equation 1) and benefit (equation 2) relating to the apprenticeship period against one another.

$$
N C_{i j}^{a}=C_{i j}^{a}-B_{i j}^{a}
$$

Cost-benefit analysis of apprenticeships in Switzerland discloses an average negative net cost for apprenticeship programs of any duration, i.e. a net profit for training firms upon completion of an apprenticeship period.

Table 2 gives an overview of the sample means for the 2352 training firms observed. The net costs are declining as the apprenticeship progresses. The total net cost means differ significantly from zero, i.e. there is a net benefit associated with training an average apprentice. 
Table 2: Cost, benefit and net cost sample means per apprentice

\begin{tabular}{|c|c|c|c|c|c|}
\hline & \multicolumn{4}{|c|}{ apprenticeship year } & \multirow[t]{2}{*}{ total } \\
\hline & 1 & 2 & 3 & 4 & \\
\hline \multicolumn{6}{|c|}{ apprenticeships lasting 3 years } \\
\hline Cost & $24^{\prime} 030$ & $26^{\prime} 288$ & $30^{\prime} 062$ & & $80^{\prime} 380$ \\
\hline Benefit & $25^{\prime} 399$ & $28^{\prime} 500$ & $33^{\prime} 982$ & & $87^{\prime} 881$ \\
\hline Net Cost & $-1 ’ 369$ & $-2 ’ 212$ & $-3^{\prime} 920$ & & $-7 ’ 501$ \\
\hline \multicolumn{6}{|c|}{ apprenticeships lasting 4 years } \\
\hline Cost & $23 ' 903$ & $24^{\prime} 656$ & $24^{\prime} 641$ & $29^{\prime} 400$ & $102^{\prime} 601$ \\
\hline Benefit & $18^{\prime} 762$ & $22^{\prime} 517$ & $30 ’ 580$ & $36^{\prime} 480$ & $108^{\prime} 338$ \\
\hline Net Cost & 5'076 & 2’065 & $-5 ’ 938$ & $-7^{\prime} 080$ & $-5,878$ \\
\hline
\end{tabular}

We find net benefits for two third of the apprentices, so only one third of apprenticeship relations end with costs that are not fully covered by benefits. In this case, the firms are obliged to retain at least some of the apprentices and recoup the uncovered cost.

A regression performed on net training costs at sites that take on apprentices (see Table 3) shows, the same as with other studies, that the size of the site has a particularly decisive influence, but that the individual occupations also generate significantly higher or lower net costs regardless of the site size.

\section{Selection models to compare net-costs of training and non-training firms}

For policy recommendations it is decisive to know whether training and nontraining firms differ in their (potential) net-cost, which we would assume from economic intuition. Using the observed data, only the net-cost of the training firms can be calculated. This was sufficient for the purpose of the descriptive costbenefit analysis above, but now we are interested in the net-cost of a randomly drawn firm in the population of all Swiss firms. Due to a potential sample selection problem, the results of the OLS-estimators in table 3 may be biased for this purpose. The problem of the non-observable net-cost of the non-training firms is treated according to standard selection models used in the literature (see Woolridge 2002). 
Table 3: Determinants of the net costs of apprenticeship training

\begin{tabular}{|c|c|c|c|c|}
\hline & Coefficient & Std. Err. & $\mathrm{z}$ & $\mathrm{P}>|\mathrm{z}|$ \\
\hline \multicolumn{5}{|l|}{ Dependent variable: Net costs } \\
\hline \multicolumn{5}{|l|}{ Sector: } \\
\hline Industrial & 10405.59 & 2922.735 & 3.56 & 0.000 \\
\hline Construction & 6381.333 & 3154.22 & 2.02 & 0.043 \\
\hline Public administration & 693.722 & 2890.594 & 0.24 & 0.810 \\
\hline French part of Switzerland & -7287.349 & 2245.662 & -3.25 & 0.001 \\
\hline Italian part of Switzerland & 11080.11 & 6080.678 & 1.82 & 0.069 \\
\hline 4-year apprenticeship & -1599.689 & 2904.433 & -0.55 & 0.582 \\
\hline \multicolumn{5}{|l|}{ Profession: } \\
\hline Commercial employee & -8508.797 & 2569.953 & -3.31 & 0.001 \\
\hline Electromechanics technician & -57655.05 & 4835.235 & -11.92 & 0.000 \\
\hline Polymechanics technician & 23048.33 & 4699.351 & 4.90 & 0.000 \\
\hline Cook & 12650.9 & 4325.882 & 2.92 & 0.003 \\
\hline IT specialist & 18443.88 & 7421.38 & 2.49 & 0.013 \\
\hline Mason & -19949.17 & 6393.641 & 3.12 & 0.002 \\
\hline Architectural draftsperson & -7077.038 & 5440.384 & -1.30 & 0.193 \\
\hline Salesperson & 4243.089 & 4539.59 & 0.93 & 0.350 \\
\hline Carpenter & -23055.22 & 4979.926 & -4.63 & 0.000 \\
\hline Dental hygienist & 4813.707 & 4753.589 & 1.01 & 0.311 \\
\hline Auto mechanic & 3035.969 & 5211.968 & 0.58 & 0.560 \\
\hline Hairdresser & -4596.799 & 4961.02 & -0.93 & 0.354 \\
\hline Office worker & -5692.122 & 9509.242 & -0.60 & 0.550 \\
\hline Assistant in a doctor's office & 3930.283 & 7242.377 & 0.54 & 0.587 \\
\hline Automation technician & 21299.62 & 7956.434 & 2.68 & 0.007 \\
\hline Electronics technician & 25035.68 & 9927.29 & 2.52 & 0.012 \\
\hline Structural draftsperson & -20647.53 & 7374.528 & -2.80 & 0.005 \\
\hline \multicolumn{5}{|l|}{ Firm-characteristics: } \\
\hline Foreign-owned company & 5347.554 & 3317.784 & 1.61 & 0.107 \\
\hline Firm size: 1-9 employees & -5028.47 & 2816.512 & -1.79 & 0.074 \\
\hline Firm size: 1-49 employees & -8862.373 & 2734.675 & -3.24 & 0.001 \\
\hline Firm size: 50-100 employees & -7472.275 & 3551.508 & 2.10 & 0.035 \\
\hline Number of apprentices & 1.580 & 7.524 & 0.21 & .834 \\
\hline Constant & -1541.015 & 3216.614 & -0.48 & 0.632 \\
\hline Number of observations & 2352 & & & \\
\hline $\mathrm{F}(28,2352)$ & 19.09 & & & \\
\hline Adj. $\mathrm{R}^{2}$ & 0.187 & & & \\
\hline
\end{tabular}

*,** 5 and 1 percent significance level respectively. The reference site is Swiss-owned company located in the German-speaking part of Switzerland, has more than 100 employees, and trains apprentices in the category "Other occupations" in the service sector. The apprenticeship period is either two or three years. 
We make the following parametric assumptions for our empirical investigation:

$N C_{j}=x_{1 j}{ }^{\prime} \beta_{1}+\varepsilon_{j}, \quad N C_{j}^{r}=x_{2 j} \beta_{2}+\eta_{j}$

where $N C_{j}^{r}$ denotes the amount of net cost the firm is ready to bear. This amount may be positive if the firm receives additional benefit from training beyond the productive work of the apprentices during apprenticeship. ${ }^{8} x_{1 j}$ is, in our case, a vector containing variables concerning firm size, industry, apprenticeship profession, region and ownership of the firm. The vector $x_{2 j}$ contains the same variables, but in addition a dummy variable that indicates if the firm has troubles finding skilled workers on the labour market (exclusion restriction) ${ }^{9}$. This variable does not influence the net-costs of the apprenticeship training, but it is expected to have a significant impact on the firm's decision to train when the net-costs of the apprenticeship training alone would be positive.

$N C_{j}$ is only observed if firm $\mathrm{j}$ trains, that is if $N C_{j}<N C_{j}^{r}$, or

$N C_{j}-N C_{j}^{r}=x_{1 j}{ }^{\prime} \beta_{1}-x_{2 j}{ }^{\prime} \beta_{2}+\varepsilon_{j}-\eta_{j}=x_{j} \delta+v<0$

With $y_{1}=N C_{j}$ and $y_{2}$ denoting the binary training indicator, the econometric model to be estimated can be written as:

$$
\begin{aligned}
& y_{1}=x_{1}{ }^{\prime} \beta_{1}+\varepsilon \\
& y_{2}=1\left[x^{\prime} \delta+v<0\right] \quad \text { where }\left(\varepsilon_{j}, v_{j}\right) \sim N\left[0,\left[\begin{array}{cc}
\sigma_{1}^{2} & \sigma_{12} \\
\sigma_{12} & 1
\end{array}\right]\right]
\end{aligned}
$$

8 These potential additional benefits include image effects, technological spill-overs that emerge through the apprentices' learning new methods in professional school, rents resulting from employing own ex-apprentices as skilled workers etc.

9 Another candidate for the exclusion restriction is the fluctuation of skilled labor in the firm. We estimated a model using both variables in the selection equation and did not find sizeable changes in the results. The underlying identification assumption is valid if the fluctuation is caused by exogenous shocks. There exists, however, evidence that apprenticeship training results in lower fluctuation for the firm (see Euwals and Winkelmann 2002), therefore we decided not to include this variable in the presented model. 
The conditional expected value of $N C_{j}$, if estimated by OLS, would be:

$$
E\left[y_{1 j} \mid x_{1 j}, y_{2 j}=1\right]=x_{1 j}{ }^{\prime} \beta_{1}+\sigma_{12} \frac{\phi\left(x_{j}^{\prime} \delta\right)}{\Phi\left(x_{j}^{\prime} \delta\right)}
$$

for training firms, and

$$
E\left[y_{1 j} \mid x_{1 j}, y_{2 j}=0\right]=x_{1 j}{ }^{\prime} \beta_{1}-\sigma_{12} \frac{\phi\left(x_{j}^{\prime} \delta\right)}{1-\Phi\left(x_{j}^{\prime} \delta\right)}, \quad \text { where } \sigma_{12}=\rho \sigma_{1}
$$

for non-training firms. If $\rho \neq 0$, then the expected value of the error term is $\varepsilon_{\mathrm{j}} \neq 0$, and the self selection problem would lead to biased estimates in the standard regression framework. To solve the problem, a maximum likelihood estimation procedure can be applied, where the log likelihood function (see Woolridge 2002) is

$$
\begin{aligned}
\ell_{j}(\theta)= & \left(1-y_{2 j}\right) \log \left[1-\Phi\left(x_{2 j} \delta\right)\right]+y_{2 j}\left(\operatorname { l o g } \Phi \left\{\left[x_{2 j} \delta+\sigma_{12} \sigma_{1}^{-2}\left(y_{1 j}-x_{1 j}{ }^{\prime} \beta_{1}\right)\right]\right.\right. \\
& \left.\times\left(1-\sigma_{12}^{2} \sigma_{1}^{-2}\right)^{-1 / 2}\right\}+\log \phi\left[\left(y_{1 j}-x_{1 j}{ }^{\prime} \beta_{1}\right) / \sigma_{1}\right]-\log \left(\sigma_{1}\right)
\end{aligned}
$$

Table 4 shows that $\rho$ differs significantly from zero. This means, that unobserved variables in $v_{j}$ are correlated with the unobserved variables in $\varepsilon_{j}$. In other words, otherwise similar non-training firms would have a significantly different net cost of training per apprentice than the firms with apprenticeships currently in place. Table 5 illustrates this on the basis of predicted net cost of non-training firms, which is in the highly positive range, amounting to somewhat more than CHF 24'500, whereas the net-costs for training firms are significantly negative. Like in Table 2, firm size is still an important factor of net costs, but now the situation is different. While large firms with more than 100 workers have to bear the highest net costs of training firms, it is now the smallest firms that have the highest cost in the full sample. This means that if all small firms in Switzerland were to train apprentices, then the average costs of training for small firms would 
rise significantly compared to larger firms. However, this is also due to the fact that most large firms already train apprentices.

Table 4: MLE selection model ${ }^{10}$ (private firms)

\begin{tabular}{|c|c|c|c|c|}
\hline & Coefficient & Std. Err. & $\mathrm{z}$ & $\mathrm{P}>|\mathrm{z}|$ \\
\hline \multicolumn{5}{|l|}{ Dependent variable: Net costs } \\
\hline Firm size $10-49$ & -8865.455 & 3634.440 & -2.440 & 0.015 \\
\hline Firm size 50-99 & -16330.150 & 5739.885 & -2.850 & 0.004 \\
\hline Firm size $>100$ & -11648.520 & 5605.389 & -2.080 & 0.038 \\
\hline Sector: Industry & 5456.060 & 4273.282 & 1.280 & 0.202 \\
\hline Construction & -906.610 & 4726.701 & -0.190 & 0.848 \\
\hline Public administration & -695.752 & 6462.861 & -0.110 & 0.914 \\
\hline French part of Switzerland & -4589.791 & 3549.619 & -1.290 & 0.196 \\
\hline Italian part of Switzerland & 23486.880 & 6736.782 & 3.490 & 0.000 \\
\hline Constant & 21651.310 & 5714.807 & 3.790 & 0.000 \\
\hline \multicolumn{5}{|l|}{ Selection model } \\
\hline Training $=1 ;$ non-training $=0$ & Coefficient & Std. Err. & $\mathrm{Z}$ & $\mathrm{P}>|\mathrm{z}|$ \\
\hline Firm size $10-49$ & 0.531 & 0.075 & 7.050 & 0.000 \\
\hline Firm size 50-99 & 1.041 & 0.183 & 5.690 & 0.000 \\
\hline Firm size $>100$ & 1.223 & 0.169 & 7.240 & 0.000 \\
\hline Sector: Industry & 0.033 & 0.082 & 0.410 & 0.681 \\
\hline Construction & 0.326 & 0.101 & 3.240 & 0.001 \\
\hline Public administration & -0.227 & 0.127 & -1.790 & 0.074 \\
\hline French part of Switzerland & -0.182 & 0.069 & -2.630 & 0.008 \\
\hline Italian part of Switzerland & -0.130 & 0.183 & -0.710 & 0.477 \\
\hline Difficulties in finding qualified 1. & 0.342 & 0.055 & 6.200 & 0.000 \\
\hline Constant & -0.759 & 0.062 & -12.280 & 0.000 \\
\hline$\rho$ & -0.538 & 0.085 & & \\
\hline$\sigma_{1}$ & 40815.870 & 1895.537 & & \\
\hline$\sigma_{12}$ & -21952.820 & 4394.795 & & \\
\hline Wald test $(\rho=0) \operatorname{chi} 2(1)$ & 25.250 & & & \\
\hline Prob $>$ chi 2 & 0.000 & & & \\
\hline Number of firms & 3632 & & & \\
\hline Number of training firms & 1971 & & & \\
\hline Number of non-training firms & 1661 & & & \\
\hline Wald chi2 (29) & 182.04 & & & \\
\hline Prob > chi 2 & 0.000 & & & \\
\hline
\end{tabular}

The reference firm is located in the German-speaking part of Switzerland, has less than 10 employees, and is in the service sector.

${ }^{10}$ Dummies for seventeen apprenticeship occupations were used in the estimate. Dummies were also used for firms of majority or full foreign ownership, in interaction with their size. These results are not stated separately owing to lack of space. 
The model hence shows that, for the apprenticeship period alone, firms that provide training are, by and large, firms where such training does not generate excess training costs and vice versa.

The significantly higher (and positive) theoretical net cost of apprenticeships for currently non-training firms may of course be attributable both to higher gross cost and lower benefit derived from the productive contribution of apprentices. The consequences in terms of educational policy would, of course, differ depending on the reason for the higher net cost. This question can be analysed using the same procedure as for estimating net cost. The selection model is identical to the one presented in Table 4. Instead of net cost, the gross cost of training is estimated followed by an estimation of the apprentices' contribution to productivity. The results are presented in Tables 6 and 7 (the detailed results of the selection models are displayed in the appendix). The correlation coefficients $\rho$ are significantly different from zero in both models, i.e. both the gross cost and productive contributions differ significantly between training and non-training sites.

Table 5: Net costs of apprenticeship training in CHF (private firms) (predicted values from a MLE selection model) ${ }^{11}$

\begin{tabular}{lccrc}
\hline \hline Sample & N of obs. & Mean $^{12}$ & Lower bound $^{13}$ & Upper bound \\
\hline Full sample & 3632 & $22^{\prime} 488.29$ & $1^{\prime}$ '538.02 & $33^{\prime} 438.57$ \\
Training firms & 1971 & $-6^{\prime} 174.35$ & $-7^{\prime} 891.32$ & $-4^{\prime} 457.37$ \\
Non-training firms & 1661 & $33^{\prime} 478.60$ & $21^{\prime} 221.76$ & $45^{\prime} 735.44$ \\
\hline \hline
\end{tabular}

The significantly higher (and positive) theoretical net cost of apprenticeships for currently non-training firms may be attributable both to higher gross cost and lower benefit derived from the productive contribution of apprentices. The consequences in terms of educational policy would, of course, differ depending on the reason for the higher net cost. This question can be analysed using the same

${ }^{11}$ The net-costs for the non-training firms are conditional on the outcome unobserved (see Vella 1998).

${ }^{12}$ The average across the entire sample is not the arithmetic mean of the two sub-samples; it is the weighted mean.

${ }^{13}$ Bounds are calculated as $95 \%$-confidence interval of the predicted means for the full sample and the non-training firms. For the training firms the confidence interval is calculated based on the observed net-costs. 
procedure as for estimating net cost. The selection model is identical to the one presented in Table 4. Instead of net cost, the gross cost of training is estimated first of all followed by an estimation of the apprentices' contribution to productivity. The results are presented in Tables 6 and 7 (the detailed results of the selection models are displayed in the appendix). The correlation coefficients $\rho$ are significantly different from zero in both models, i.e. both the gross cost and productive contributions differ significantly between training and non-training sites.

As expected, the likely cost of training is higher for non-training firms than for training firms. However, the difference (somewhat more than CHF 10,000, table 6) is fairly minor compared with the net cost differential of more than CHF 40,000 (see Table 5).

Table 6: Costs of apprenticeship training in CHF (private firms) (predicted values from a MLE selection model)

\begin{tabular}{lcccc}
\hline \hline Sample & N of obs. & Mean & Lower bound & Upper bound \\
\hline Full sample & 3632 & $97^{\prime} 262.60$ & $91^{\prime} 365.13$ & $103^{\prime} 164.8$ \\
Training firms & 1971 & $87^{\prime} 443.26$ & $85^{\prime} 913.24$ & $88^{\prime} 973.29$ \\
Non-training firms & 1661 & $100^{\prime} 969.80$ & $94^{\prime} 501.56$ & $107^{\prime} 438.10$ \\
\hline \hline
\end{tabular}

Table 7: Benefit of apprenticeship training in CHF (private firms) (predicted values from a MLE selection model)

\begin{tabular}{lcccc}
\hline \hline Sample & N of obs. & Mean & Lower bound & Upper bound \\
\hline Full sample & 3632 & $50^{\prime} 391.51$ & $42^{\prime} 303.45$ & $58^{\prime} 468.48$ \\
Training firms & 1971 & $91^{\prime} 914.02$ & $90^{\prime} 500.07$ & $93^{\prime} 327.98$ \\
Non-training firms & 1661 & $34^{\prime} 391.09$ & $24^{\prime} 907.70$ & $43^{\prime} 874.48$ \\
\hline
\end{tabular}

The outcome is somewhat different as regards the likely productivity benefits (table 7) accruing from apprenticeships. The difference between training and nontraining firms is highly significant in this respect, amounting to approximately CHF 60,000.

The results in Tables 6 and 7 cannot legitimately be added up and compared with the data in Table 5, as the addition of gross cost and benefit for individual sites generates different individual net cost averages than the addition of the overall 
average gross cost and benefit. The estimates clearly show that the source of the significantly higher net cost for non-training firms is rooted in the very much lower expected benefit. The absence of benefit has several possible causes. It may be because the firms in question have little work for potential apprentices quite simply because of the particular workforce qualification structure, or because unskilled workers are paid low wages, leaving little room for cutting costs through the deployment of apprentices. On the whole, the results underline the importance of apprentices' contribution to productivity as a factor in making it worth a company's while to offer apprenticeships, and thus as a crucial factor in determining a company's willingness to provide training. Evidence that the productive deployment of apprentices need not detract from the quality of the training provided is shown by the high level of qualification of Swiss apprentices compared with their peers in other countries, as mentioned above. The importance of productive benefit for the Swiss vocational education system is in contrast to other vocational training systems, some of which are focused to a much lesser degree on productivity benefits during apprenticeship. ${ }^{14}$

\section{Discussion}

Vocational training policy debate in recent years has centred on labour market regulation and institutions (see e.g. Acemoglu and Pischke 1998). The data presented here should constitute a basis for shifting the focus to another aspect of vocational education, namely how training is organized and regulated within firms. Analysis of the Swiss vocational training system has shown that the training of apprentices in most cases pays for itself within the training period. As a result, firms that train apprentices are not dependent on a regulated labour market and low workforce mobility to make training worth their while. Under these general circumstances, training and non-training firms differ more in terms

\footnotetext{
14 A French-German comparison by Fougère and Schwerdt (2002) disclosed for example that, except for midsized enterprises, apprentices did not make a meaningful contribution to a company's operating result. The motivation for companies to train apprentices was identified as being easier recruitment of future skilled workers, and the possibility of longer and more costeffective screening of potential employees. Additionally, in Schweri et al. (2003, p. 84) it was shown that if one compares costs and benefits between Swiss and German enterprises, the training of an apprentice in Switzerland costs some 15\% more than in Germany but the productive contribution is about $150 \%$ higher than the one in Germany.
} 
of the likely net cost of training during the apprenticeship period and less in terms of the labour market factors. The paper also shows that the major part of the difference in the net cost of training apprentices is due to a difference in the extent of benefit accruing from apprentices' productive contribution and is not attributable to differences in the cost of training. This insight helps to identify a weak point of the Swiss vocational training system, namely that many firms will provide training only if there is work to be done that can usefully and productively be entrusted to apprentices. Technological progress, the associated changes in demand for professional qualifications as well as economic fluctuations all have a significant influence on the amount of work that can be performed by apprentices and a commensurate impact on the number of apprenticeships provided.

The results presented here are also of significance with respect to the ongoing educational policy debate. There have been repeated calls in the past to raise the number of apprenticeships on offer by stopping non-training companies from getting a free ride. This proposed solution would have all companies, training and non-training, contribute a certain amount of money to a fund for apprenticeship training. The sums from this fund would then be used to support all companies providing training. Training would thus become more profitable, and the willingness to provide training would be greater because training companies that lose a graduated apprentice to a rival company would not stand to lose as much as before. This policy instrument for taxing non-training companies was based on the assumption that companies could not offset the cost accrued within an apprenticeship period. As has been seen, this does not apply to the majority of training firms, at least in Switzerland. That is not to say that this instrument would be wholly absurd, as the data shows that non-training companies probably do not provide training precisely because it would not be worth their while. The revenue from this kind of tax instrument might therefore help today's non-training firms to "break even" if they were to provide training. However, the data from our analysis of the cost-benefit ratio of training apprentices suggest that an incentive of this kind would make no sense for pedagogic reasons alone. This is because the lack of benefit for non-training firms must be interpreted as a sign that these companies have no suitable activities to assign to apprentices. It would be a different situation if the higher net cost had been due to a higher cost of training. The creation of more apprenticeships is and remains a difficult undertaking. We must 
come to terms with the fact that vocational training is a market-directed section of the educational system and as such exposed to free market forces. To date, these market forces have not been dysfunctional in terms of producing irrational or inefficient responses on the part of industry and the business community. As such, there can be little justification for state intervention in the vocational educational market.

Finally, if we look across borders, the upbeat message for the German debate on the future of vocational education from this analysis of the Swiss situation is: Contrary to frequently expressed fears ${ }^{15}$, labour market deregulation ${ }^{16}$ is not the death knoll for vocational training. Its viability would, however, presuppose that apprenticeship training is more cost-effective than is currently the case in Germany. More cost-effective does not mean having to accept a reduction in the quality of the training provided. What it does mean is that the participation of apprentices in the production process of the training firm must be thought through and implemented more systematically than has been the case. It would also require more room for manoeuvre for the firms to set the parameters of employing and training apprentices, like the apprentices' wages, more freely from general regulations, in order to be able to adapt in a more flexible way to market requirements. Contrary to the line of argument often used, we assume that the future of German-style vocational education does not inevitably depend on a regulated labour market but it is because of this labour market regulations, that the German system so far does not seem to optimise the cost-benefit ratio in vocational training.

${ }^{15}$ Beckmann (2002) concludes as follows: "A continuing deregulation in terms of weakening the influence of unions or works councils would probably be at the expense of the firms' willingness to pay for general skill accumulation." (p. 385).

16 Compared to the Germany the Swiss labour market is much more deregulated. The OECD employment outlook (1999: 57), for instance, contains indicators of the overall strictness of protection against dismissals, where Switzerland is ranked $5^{\text {th }}$ and Germany $21^{\text {st }}$ of 26 ranked OECD countries in the late 1990s (sorted from least strict to strictest). 


\section{Bibliography}

Acemoglu, Daron and Pischke, Jörn-Steve (1998): Why do Firms train? Theory and Evidence, Quarterly Journal of Economics, 113, 79-119.

Bardeleben v., Richard, Beicht, Ursula and Fehér, Kálmán (1995): Betriebliche Kosten und Nutzen der Ausbildung: repräsentative Ergebnisse aus Industrie, Handel und Handwerk, Bielefeld: Bertelsmann.

Beckmann, Michael (2002): Wage Compression and Firm-Sponsored Training in Germany: Empirical Evidence for the Acemoglu-Pischke Model from a Zero-inflated Count Data Model, Applied Economics Quarterly (Konjunkturpolitik), 48 (3-4), 368-387.

Beicht, Ursula and Walden, Günter (2002): Wirtschaftlichere Durchführung der Berufsausbildung - Untersuchungsergebnisse zu den Ausbildungskosten der Betriebe, Berufsbildung in Wissenschaft und Praxis, 6/2002, Bonn: BiBB.

Bierhoff, Helvia and S.J. Prais (1997): From school to productive work. Britain and Switzerland compared. The National Institute of Economic and Social Research. Cambridge: Cambridge University Press.

Euwals, Rob and Winkelmann, Rainer (2002: Mobility after Apprenticeship - Evidence from Register Data, Applied Economics Quarterly (Konjunkturpolitik), 48 (3-4), 256-278.

Fougère, Denis and Schwerdt Wolfgang (2002): Are Apprentices Productive?, Applied Economics Quarterly (Konjunkturpolitik), 48 (3-4), 317-346.

Hanhart, Siegfried and Schulz, Hans-Rudolf (1998): Lehrlingsausbildung in der Schweiz, Chur/Zürich.

OECD (1999): Employment Outlook, Paris: OECD.

OECD (2000): From Initial Education to Working Life: Making Transitions Work, Paris: OECD.

Potterat, Jann (2003): Kosten und Nutzen der Berufsbildung im Jahr 2001 aus der Sicht der Betriebe. Schätzverfahren. Neuenburg: Bundesamt für Statistik.

Renfer, Jean-Pierre (2002): Enquête 2001 sur les coûts et l'utilité de la formation des apprentis du point de vue des établissements, Neuchâtel : Office fédéral de la statistique.

Ryan, Paul (1998): Is Apprenticeship Better? A Review of the Economic Evidence, Journal of Vocational Education and Training, Vol. 50, No.2, 289-325.

Schweri, Jürg, Mühlemann, Samuel, Pescio, Yasmina, Walther, Belinda, Wolter, Stefan C. and Zürcher, Lukas (2003): Kosten und Nutzen der Lehrlingsausbildung aus der Sicht Schweizer Betriebe, Beiträge zur Bildungsökonomie, Band 2, Chur \& Zürich: Rüegger Verlag.

Vella, Francis (1998): Estimating Models with Sample Selection Bias: A Survey, The Journal of Human Resources, Vol. 33(1), 127-169.

Walden, Günter and Herget, Hermann (2002): Nutzen der betrieblichen Ausbildung für Betriebe - erste Ergebnisse einer empirischen Erhebung, Berufsbildung in Wissenschaft und Praxis, 6/2002, Bonn: BiBB.

Weber, Bernhard, A., Wirz, Aniela and Wolter, Stefan C. (2001): Switzerland, in: (C. Harmon, I. Walker and N. Westergaard-Nielsen, eds.), Education and Earnings in Europe. Cheltenham: Edward Elgar.

Wolter Stefan C. and Schweri Jürg (2002): The Cost and Benefit of Apprenticeship Training: The Swiss Case, Applied Economics Quarterly (Konjunkturpolitik), 48 (3-4), 347-367.

Wooldridge, Jeffrey M. (2002): Econometric analysis of cross section and panel data, Cambridge, Massachusetts: The MIT Press. 


\section{Appendices}

Table 8: Sample descriptives

\begin{tabular}{|c|c|c|c|}
\hline Variable & Obs. & Mean & Std. Dev. \\
\hline Training Firm & 3632 & 0.291 & 0.454 \\
\hline Firm size 1-9 & 3632 & 0.734 & 0.442 \\
\hline Firm size $10-49$ & 3632 & 0.224 & 0.417 \\
\hline Firm size 50-99 & 3632 & 0.023 & 0.151 \\
\hline Firm size $>100$ & 3632 & 0.019 & 0.135 \\
\hline Sector: Service & 3632 & 0.679 & 0.467 \\
\hline Industry & 3632 & 0.136 & 0.343 \\
\hline Construction & 3632 & 0.119 & 0.324 \\
\hline Public Administration & 3632 & 0.066 & 0.248 \\
\hline German part of Switzerland & 3632 & 0.750 & 0.433 \\
\hline French part of Switzerland & 3632 & 0.222 & 0.416 \\
\hline Italian part of Switzerland & 3632 & 0.029 & 0.167 \\
\hline Foreign firm ownership & 3632 & 0.116 & 0.320 \\
\hline Foreign firm ownership*Firms size 1-9 & 3632 & 0.071 & 0.257 \\
\hline Foreign firm ownership*Firms size 10-49 & 3632 & 0.036 & 0.186 \\
\hline Foreign firm ownership*Firms size 50-99 & 3632 & 0.004 & 0.065 \\
\hline Foreign firm ownership*Firms size $>100$ & 3632 & 0.004 & 0.065 \\
\hline Difficulties in finding qualified labour & 3632 & 0.403 & 0.491 \\
\hline Commercial employee & 3632 & 0.177 & 0.381 \\
\hline Polymechanics technician & 3632 & 0.019 & 0.136 \\
\hline IT specialist & 3632 & 0.028 & 0.164 \\
\hline Cook & 3632 & 0.070 & 0.255 \\
\hline Electromechanics technician & 3632 & 0.020 & 0.139 \\
\hline Mason & 3632 & 0.025 & 0.157 \\
\hline Architectural draftsperson & 3632 & 0.030 & 0.171 \\
\hline Salesperson & 3632 & 0.062 & 0.242 \\
\hline Auto mechanic & 3632 & 0.020 & 0.141 \\
\hline Carpenter & 3632 & 0.025 & 0.155 \\
\hline Dental hygienist & 3632 & 0.026 & 0.159 \\
\hline Office worker & 3632 & 0.034 & 0.186 \\
\hline Assistant in a doctor's office & 3632 & 0.021 & 0.145 \\
\hline Automation technician & 3632 & 0.004 & 0.063 \\
\hline Electronics technician & 3632 & 0.004 & 0.064 \\
\hline Structural draftsperson & 3632 & 0.010 & 0.100 \\
\hline Hairdresser & 3632 & 0.017 & 0.129 \\
\hline
\end{tabular}


Table 9: MLE selection model ${ }^{17}$ (Gross cost)

\begin{tabular}{|c|c|c|c|c|}
\hline & Coefficient & Std. Err. & $\mathrm{z}$ & $\mathrm{P}>|\mathrm{z}|$ \\
\hline \multicolumn{5}{|l|}{ Dependent variable: Gross costs } \\
\hline Firm size $10-49$ & -391.507 & 2570.633 & -0.150 & 0.879 \\
\hline Firm size 50-99 & -4895.293 & 3897.817 & -1.260 & 0.209 \\
\hline Firm size $>100$ & 1920.055 & 3559.897 & 0.540 & 0.590 \\
\hline Sector: Industry & 14842.860 & 3436.376 & 4.320 & 0.000 \\
\hline Construction & 6731.784 & 3470.860 & 1.940 & 0.052 \\
\hline Public administration & 1449.762 & 4501.194 & 0.320 & 0.747 \\
\hline French part of Switzerland & -6923.695 & 2347.070 & -2.950 & 0.003 \\
\hline Italian part of Switzerland & 6704.784 & 5479.063 & 1.220 & 0.221 \\
\hline Constant & 94948.930 & 3497.982 & 27.140 & 0.000 \\
\hline \multicolumn{5}{|l|}{ Selection model } \\
\hline Training $=1 ;$ non-training $=0$ & Coefficient & Std. Err. & $\mathrm{Z}$ & $\mathrm{P}>|\mathrm{z}|$ \\
\hline Firm size $10-49$ & 0.525 & 0.075 & 6.990 & 0.000 \\
\hline Firm size 50-99 & 1.035 & 0.183 & 5.650 & 0.000 \\
\hline Firm size $>100$ & 1.206 & 0.167 & 7.230 & 0.000 \\
\hline Sector: Industry & 0.031 & 0.081 & 0.390 & 0.700 \\
\hline Construction & 0.322 & 0.101 & 3.200 & 0.001 \\
\hline Public administration & -0.228 & 0.127 & -1.800 & 0.072 \\
\hline French part of Switzerland & -0.187 & 0.069 & -2.700 & 0.007 \\
\hline Italian part of Switzerland & -0.138 & 0.183 & -0.750 & 0.450 \\
\hline Difficulties in finding qualified 1. & 0.351 & 0.057 & 6.110 & 0.000 \\
\hline Constant & -0.759 & 0.063 & -12.120 & 0.000 \\
\hline$\rho$ & -0.294 & 0.064 & & \\
\hline$\sigma_{1}$ & 31269.670 & 969.217 & & \\
\hline$\sigma_{12}$ & -9189.401 & 2179.000 & & \\
\hline Wald test $(\rho=0) \operatorname{chi} 2(1)$ & 18.51 & & & \\
\hline Prob $>$ chi 2 & 0.000 & & & \\
\hline Number of firms & 3632 & & & \\
\hline Number of training firms & 1971 & & & \\
\hline Number of non-training firms & 1661 & & & \\
\hline Wald chi2 (29) & 573.55 & & & \\
\hline Prob > chi2 & 0.000 & & & \\
\hline
\end{tabular}

The reference firm is located in the German-speaking part of Switzerland, has less than 10 employees, and is in the service sector.

${ }^{17}$ Dummies for seventeen apprenticeship occupations were used in the estimate. Dummies were also used for firms of majority or full foreign ownership, in interaction with their size. 
Table 10: MLE selection model ${ }^{18}$ (Benefit)

\begin{tabular}{|c|c|c|c|c|}
\hline & Coefficient & Std. Err. & $\mathrm{z}$ & $\mathrm{P}>|\mathrm{z}|$ \\
\hline \multicolumn{5}{|l|}{ Dependent variable:Benefit } \\
\hline Firm size $10-49$ & 16499.980 & 3190.487 & 5.170 & 0.000 \\
\hline Firm size 50-99 & 26321.800 & 5073.775 & 5.190 & 0.000 \\
\hline Firm size $>100$ & 31166.220 & 4708.122 & 6.620 & 0.000 \\
\hline Sector: Industry & 10062.760 & 3528.101 & 2.850 & 0.004 \\
\hline Construction & 12724.040 & 3808.037 & 3.340 & 0.001 \\
\hline Public administration & -2607.620 & 5438.766 & -0.480 & 0.632 \\
\hline French part of Switzerland & -5182.421 & 3063.519 & -1.690 & 0.091 \\
\hline Italian part of Switzerland & -17561.210 & 5514.872 & -3.180 & 0.001 \\
\hline Constant & 48628.740 & 4543.714 & 10.700 & 0.000 \\
\hline \multicolumn{5}{|l|}{ Selection model } \\
\hline Training $=1 ;$ non-training $=0$ & Coefficient & Std. Err. & $\mathrm{Z}$ & $\mathrm{P}>|\mathrm{z}|$ \\
\hline Firm size $10-49$ & 0.544 & 0.073 & 7.410 & 0.000 \\
\hline Firm size 50-99 & 1.041 & 0.173 & 6.030 & 0.000 \\
\hline Firm size $>100$ & 1.189 & 0.157 & 7.580 & 0.000 \\
\hline Sector: Industry & 0.037 & 0.082 & 0.450 & 0.655 \\
\hline Construction & 0.318 & 0.098 & 3.230 & 0.001 \\
\hline Public administration & -0.230 & 0.126 & -1.820 & 0.069 \\
\hline French part of Switzerland & -0.158 & 0.069 & -2.280 & 0.023 \\
\hline Italian part of Switzerland & -0.136 & 0.175 & -0.780 & 0.436 \\
\hline Difficulties in finding qualified 1. & 0.271 & 0.049 & 5.480 & 0.000 \\
\hline Constant & -0.726 & 0.061 & -11.990 & 0.000 \\
\hline$\rho$ & 0.831 & 0.042 & & \\
\hline$\sigma_{1}$ & 37313.730 & 2022.166 & & \\
\hline$\sigma_{12}$ & 31010.370 & 3155.278 & & \\
\hline Wald test $(\rho=0) \operatorname{chi} 2(1)$ & 78.02 & & & \\
\hline Prob $>$ chi 2 & 0.000 & & & \\
\hline Number of firms & 3632 & & & \\
\hline Number of training firms & 1971 & & & \\
\hline Number of non-training firms & 1661 & & & \\
\hline Wald chi2 (29) & 436.84 & & & \\
\hline Prob $>$ chi 2 & 0.000 & & & \\
\hline
\end{tabular}

The reference firm is located in the German-speaking part of Switzerland, has less than 10 employees, and is in the service sector.

${ }^{18}$ Dummies for seventeen apprenticeship occupations were used in the estimate. Dummies were also used for firms of majority or full foreign ownership, in interaction with their size. 


\section{IZA Discussion Papers}

\begin{tabular}{|c|c|c|c|c|}
\hline No. & Author(s) & Title & Area & Date \\
\hline 902 & $\begin{array}{l}\text { P. Frijters } \\
\text { M. A. Shields } \\
\text { S. Wheatley Price }\end{array}$ & $\begin{array}{l}\text { Immigrant Job Search in the UK: Evidence from } \\
\text { Panel Data }\end{array}$ & 1 & $10 / 03$ \\
\hline 903 & $\begin{array}{l}\text { S. Girma } \\
\text { H. Görg }\end{array}$ & $\begin{array}{l}\text { Evaluating the Causal Effects of Foreign } \\
\text { Acquisition on Domestic Skilled and Unskilled } \\
\text { Wages }\end{array}$ & 2 & $10 / 03$ \\
\hline 904 & $\begin{array}{l}\text { S. P. Jenkins } \\
\text { P. Van Kerm }\end{array}$ & $\begin{array}{l}\text { Trends in Income Inequality, Pro-Poor Income } \\
\text { Growth and Income Mobility }\end{array}$ & 1 & $10 / 03$ \\
\hline 905 & $\begin{array}{l}\text { D. Weichselbaumer } \\
\text { R. Winter-Ebmer }\end{array}$ & $\begin{array}{l}\text { Rhetoric in Economic Research: The Case of } \\
\text { Gender Wage Differentials }\end{array}$ & 7 & $10 / 03$ \\
\hline 906 & $\begin{array}{l}\text { D. Weichselbaumer } \\
\text { R. Winter-Ebmer }\end{array}$ & $\begin{array}{l}\text { A Meta-Analysis of the International Gender } \\
\text { Wage Gap }\end{array}$ & 7 & $10 / 03$ \\
\hline 907 & $\begin{array}{l}\text { A. Dupuy } \\
\text { L. Borghans }\end{array}$ & $\begin{array}{l}\text { Supply and Demand, Allocation and Wage } \\
\text { Inequality: An International Comparison }\end{array}$ & 1 & 10/03 \\
\hline 908 & M. Leonardi & Product Demand Shifts and Wage Inequality & 1 & $10 / 03$ \\
\hline 909 & M. Leonardi & $\begin{array}{l}\text { Firm Heterogeneity in Capital/Labor Ratios and } \\
\text { Wage Inequality }\end{array}$ & 1 & $10 / 03$ \\
\hline 910 & $\begin{array}{l}\text { P. Díaz-Vázquez } \\
\text { D. Snower }\end{array}$ & $\begin{array}{l}\text { On-the-Job Training, Firing Costs and } \\
\text { Employment }\end{array}$ & 5 & $10 / 03$ \\
\hline 911 & J. Wagner & $\begin{array}{l}\text { Are Nascent Entrepreneurs Jacks-of-all-Trades? } \\
\text { A Test of Lazear's Theory of Entrepreneurship } \\
\text { with German Data }\end{array}$ & 5 & $10 / 03$ \\
\hline 912 & $\begin{array}{l}\text { D. Checchi } \\
\text { A. Filippin }\end{array}$ & An Experimental Study of the POUM Hypothesis & 1 & $10 / 03$ \\
\hline 913 & $\begin{array}{l}\text { S. Pivnenko } \\
\text { D. DeVoretz }\end{array}$ & $\begin{array}{l}\text { The Recent Economic Performance of Ukrainian } \\
\text { Immigrants in Canada and the U.S. }\end{array}$ & 1 & $10 / 03$ \\
\hline 914 & $\begin{array}{l}\text { A. R. Cardoso } \\
\text { P. Portugal }\end{array}$ & $\begin{array}{l}\text { Bargained Wages, Wage Drift and the Design of } \\
\text { the Wage Setting System }\end{array}$ & 5 & $10 / 03$ \\
\hline 915 & $\begin{array}{l}\text { R. Hujer } \\
\text { C. Zeiss }\end{array}$ & $\begin{array}{l}\text { Macroeconometric Impacts of ALMP on the } \\
\text { Matching Process in West Germany }\end{array}$ & 6 & $10 / 03$ \\
\hline 916 & $\begin{array}{l}\text { S. C. Wolter } \\
\text { S. Mühlemann } \\
\text { J. Schweri }\end{array}$ & $\begin{array}{l}\text { Why Some Firms Train Apprentices and Many } \\
\text { Others Do Not }\end{array}$ & 5 & $10 / 03$ \\
\hline
\end{tabular}

An updated list of IZA Discussion Papers is available on the center's homepage www.iza.org. 